\title{
On quest of environmental tax implementation in Indonesia
}

\author{
Edi Slamet Irianto $^{1}$, Haula Rosdiana $^{2, *}$, and Maria RUD Tambunan ${ }^{2}$ \\ ${ }^{1}$ Graduate Program of Tax Policy and Administrative Science, Faculty Administrative Sciences, \\ Universitas Indonesia, Depok, Indonesia \\ ${ }^{2}$ Faculty of Administrative Sciences, Universitas Indonesia, Depok, Indonesia
}

\begin{abstract}
The number of research evaluating the implementation of environmental tax using regulatory cost perspective is still limited. Whereas, this type of research is quite crucial in formulating tax policy to find the balance between regulatory function, revenue productivity and its impact on maintaining conducive business climate. Therefore, this research is aimed to elaborate types of environmental taxes applied in Indonesia, to map the problems arised of their implementation and their impact on regulatory compliance cost. This research occupied postpositivism paradigm with mixed method approach. The data were gathered through qualitative and quantitative technique. The result shows that eventhough Indonesia has not implement explicity a new environmental tax, there are a lot of quasienvironmental tax scatterly levied by local government and provincial government due to their authority given by the decentralization besides the corporate social responsibility performed by the business entities. Unfortunately, the reallocation budget framework on the tax/charged levied from the quasi-environmental tax has not been clear. Thus, it is essential to establish a comprehensive environmental tax with an integrated roadmap considering and accomodating the former quasi-environmental tax into a one package environmental tax policy with clear concept of earmarking with efficient collection cost.
\end{abstract}

\section{Introduction}

The issue of environmental tax re-arised in Indonesia in a parallel with the shifting paradigmn of economic development framework during Susilo Bambang Yudhoyono presidential era. During that era, to rearch the high quality of economic development, the government took a lead to optimize the intensity of inclusive economic growth and sustainable development by taking attention on environmental aspects. To reachthe goal, inclusive economic growth strategies were based on four fundamental principles namely(a) to optimize the high quality of economic growth (pro-growth), (b) to exentesify employment opportunity (pro-job), (c) to improve social welfare by implementing social security-related programs with specific low economic target (pro-poor) and (d) to improve the waste management and environment preservation (pro-environment) [1].

\footnotetext{
*Corresponding author: h.rosdiana@ui.ac.id
} 
Factually, taxation has been occupied as an instrument to control and to prevent the environment degradation as stated in the Environmental Act No.4 year 1982. However, the type of disincentives/levies or incentives on environmental management were not clearly stated in the act [2]. The government's authority to levy environment-related tax implicitly solely was given through State Financial Act, Local Government Act and Local Tax and User Charge Act then the implementation authority of levying environmental-related taxes can be undertaken by Local Government [3].

Eventhough the legal and conceptual framework of levying environmental tax has existed, its implementation is arduous. From business perspective, the double payments on the tax (general tax as well as other taxes) is burdensome.. Similary, the former Minister of Industrial Affrair also rejected the initiation to levy a specific environmental tax by arguing that the enforce the law for activities causing environmental damage was more effective than impose environmental tax. In addition, the Minister also highlight that mobilize revenue throught environment tax will lead double tax burden [4].

It is important to note that in reality, there are number of quasi-environment taxand user charge levied, should be paid by the business. In addition, unfortunately, the imposition of such quasi-environment tax and/or user charge has not been place on a comprehensive framework collected budget allocation through earmark projects with strong legal basis [5]. Therefore, this article will comprehensively examine the why the environmental tax failed to be implemented in Indonesia. Further, this article also intended to discuss the implementation of existing quasi-environmental tax in Indonesia.

The nature function of levying taxes is as budgetary and regulatory function. With regard to its regulatory function, citing Zolt saying that the tax system can be used to encourage or discourage certain activities [6]. On public finance theory, Mankiew said that " negative externalities lead market to produce a larger quantity that is socially desirable, whereas positive externalities lead the market to produce a smaller quantity that is socially desirable [7]. To remedy the problem, the government can internalize the externality by taxing goods that have negative externalities and subsizing goods that have positive externalities.In addition, Seidman $(2009,22)$ posed that when negative externalities exist means that market could not optimally produces goods and services, for the supply of public goods or public services which could not produce by the market mechanism, there will be the potential of free rider. Seidman further stated that the feasible solution to minimize free rider is through imposing tax[8]. Similarly as Hinman stated that "the government should use taxes or subisies to correct for failure of self-interested buyers and sellers to account for the effect on their decision on others" [9].

Based on KPMG survey in 2013, large number of countries occupied tax mechanism to influence and to enforce the business behavior or people specifically to internalize the environment preservation and sustainable development aspect on their business plan [10]. In implementing environmental tax, The UN-ESCAP (2012) propose that the idea of taxing the negative externalities with the premises of revenue neutrality and "double dividend" is a powerful tool toward green growth. On the UN-ESCAP perspective, imposing environmental tax means there will be a shift of tax burden from conventional taxes levying from environment damaging activites into a new concept of environmental taxes. The imposition of environmental taxes is a appropriate mechanism to bring the market prince together with cost of environment externalities [11]. To desing the environmental tax, OECD provide the principle and guidance, the highligh of them are as follow [12].

a. The target of enviromental tax subject should be clear for example, the pollutant or polluting behavior with particular exception.

b. The scope of environmental damage catagories should not be larger than the scope of environmental tax base

c. The tax rate should be cover the externality in exchange of 
d. The tax burden should be predictable as the base calculation for future environmental quality improvement

e. The environmental tax burden should be able to consolidate with other fiscal obligation

f. The impact realocation of revenue mobilized should be addressed through other policy instruments

g. The environmental tax imposed should not prevent the business to be competitive.

h. The government need to comprehensively socialize the levies in order to get acceptance from public

i. Environmental taxes should be combined with other instrument aiming to address the certain similar issues

In fact, the success of policy implementation including the initiation of enviromental tax implementation is affected by the resiliency of enviroment strategic both external state and/or internal state toward the achievable sustainable development objective. A State resilency is determined by natural resilency aspect (trigatra) and socio-political resiliency (pancagatra). The natural resilency aspect consisted of geographical aspect, natural resources availability and number of citizen. Whereas, the socio-political resiliency is constructed from ideology, politics, economy, social culture and national security [13]

Recalling the aim of this research to examine why the environmental tax failed to be implemented and to examine the existence of quasi-environmental tax in Indonesia, the perspective of natural resilency aspect (trigatra) and socio-political resiliency (pancagatra) will be the base premises of research guidance. In order to conduct the research, it use postpositivist paradigm with mix method approach. The data was collected through qualitative and quantitative technic. The qualitative technice has been done through literature study, indepth interview and focus group discussion, whereas the quantitative technice has been done through the construction of model depict the phonomenon by applying sistem dynamic as a research tool.

\section{Method}

This research occupied postpositivism paradigm with mixed method approach. The data were gathered through qualitative and quantitative technique. Data and information was collected through literature study and field research. A series of in depth interview has been conducted to the relevant informants; Directorate General of Taxes and Fiscal Policy Office Ministry of Finance, Ministry of Energy and Mineral Resources, Ministry of Environmental Affairs, Business Practititoners.

\section{Results and discussion}

In the initial plan of environmental tax, by injecting the concept of "polluter pays principle", the subject of environmental tax is the manufacture business entities that its omzet morethan IDR 300 million per year. Whereas, the object of environmental tax is the production activities that give an added value from raw material into new product and waste by using natural resources as main materian of supporting material. For the production volume below IDR 300 million, the environmental rate tax would be $0,5 \%$ from production cost [14].

Refering to the basic principle of tax policy, a good tax policy should be clearly stated the subject, object, exemption of object, tax base, tax rate and other related to the element of tax imposition. Examining the proposed environmental tax, for example, the entitled subject has not been clearly defined to what extend the scope of manufacturing should be, similarly the exemption of tax subject and criteria of subject and exempted subject. If the determination of tax subject solely rely of legal formal of industry, it will be easily faded on their legal 
corporate documents. In designing a tax policy if these elements has not been clear, there will be a potential shifting environmental tax burden into production cost.

It means the consumer indirectly has to pay the externalities perform by business entity as part of their production process which should not be paid by customer, means like another indirect tax character, it would bear regressive effect. In fact, when the initiated environmental tax went to public hearing, it was revelead that besides the direct money cost has to be paid for environmental tax it self, this type of tax is a trigger to generate another cost, for example environment impact analysis fees and other fees has to paid with related to environmental affairs[15]. Economically, there will be higher shifting burden into production cost then have to paid by the consumer lead to less competitive price level of products. Unfortunately, the incentive will be given if a business implement or comply with the initiated regulation has not been precisely stated.

For the practical aspect, there are range of options as the convergence of environmental tax. The OECD in 2011 offer several implementing policy preferable to reduce specific environmental problem such as minimum fuel efficiency rate for machinery or vehichle, the subsidy for efficient energy used. Of course, it will need specific comprehensive data including the business changing or even technoly replacement into more sophisticated ones to get fair calculation of burden. It cannot be blamed that cost of levying of the "fair" environmental tax is considerably high.

In Indonesia, the debate of environmetal tax relate to the issue; the imposition of enviromental tax would have been legitimized by the Act Bill of Environmental Tax seems abuse its regulatory function to preserve the natural resource and prevent environmental degration, instead it would be intended to optimize the budgatary function. In addition, for the developing and industrial countries, the high economic growth with intensive goods and service production is more priority. It means high priority economic growth unavoidable will produce another by product with high used of energy. For the infant industry and small and medium enterprises which most use less sophisticated technology, it probably will leash them to operate efficient business.

Eventhough Indonesia has not been imposed environmental tax, several quasienvironmental tax has been imposed as regulated in Local Tax and User Charge Act. The quasi-environmental tax consist of tax on the used or upper soil water, tax on vehichle used, tax on gasoline, user charge/fees for disturbance, charge for light waste recycle and other types of fees stipulated by particular local government or provincial government. Taking example in Jakarta province, up to 2013, the Governor with Provincial House of Representative has agree to relase regulation for imposing 12 types of local tax including quasi-environmental taxes. Annually, the contribution of tax on the used or upper soil water, tax on vehichle used, tax on gasoline, tax on road electricity on Jakarta potential revenue province is about $60 \%$ from the total Own-source Revenue [16].

However, the provincial government has not set the allocation management framework of money collected which specifically go to environmental affair. The provincial do not have clear purposes and expected outcomes of earmark concept eventhough the Local Tax and User Charge Act mentioned that minimum of $10 \%$ from tax revenue shall be allocated to environmental and natural preservation affair. In addition, up to $70 \%$ of total budget annually goes to civil servent salary expenditure item. Whether this pattern of spending trend is similar with other local government or provincial government, it needs to examined comprehensively [17].

Besides imposition of taxes, business entities also are obliged to comply with other environmental related obligation such as Corporate Social Responsibility (CSR), performance bonds, AMDAL (stands for Analisis Mengenai Dampak Lingkungan Hidup), obligatory fees to conduct environmental analysis, and UKL-UPL (stands for Upaya Pengelolaan Lingkugan Hidup (UKL) dan Upaya Pemantauan Lingkungan Hidup), 
obligatory fees to manage and to monitor environmetal externalities.. The obligation to perform CSR is entitledto entreprises which its main work relate to natural resources, energy used, environmetal degradation. This obligation has been legally mentioned in Corporate Act No.40 year 2007 [18]. Failure to comply with this obligation will lead the entities on verdict. On the other hand, whether the fees paid as CSR obligation balance to the cost of environment degradation is need to reexamined eventhough no special incentives given to the comply enterprises or disincentive. Another problem is that no specific treatment taken by the government if CSR project is not inline with the initial goal.

Important to note that, environmental tax, quasi-environmental tax and other state levies related to environmental problems in fact will bear regulatory compliance cost adding the burden of business. As OECD stated that, each regulation will arise its regulatory system. The term regulation means the varies of instrument package completed by requirements applicable to business or citizen. The regulation exists in form of formal and informal rules, subordinate rules issued by all level of government, non-governmental institution or selfregulatory agency which has authority given by the government.

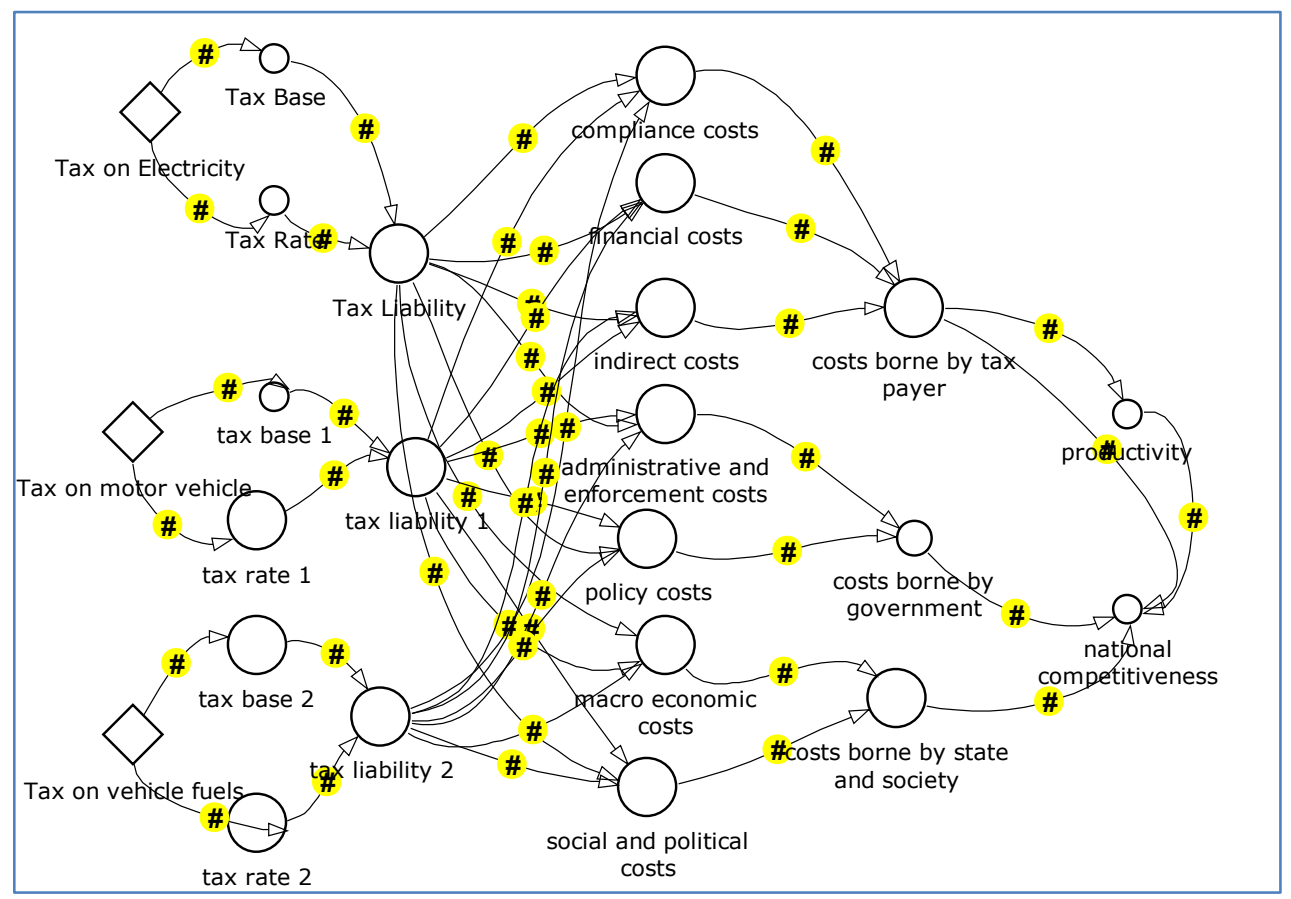

Fig. 1. Regulatory costs arised by implementing environmental taxes.

Figure 1. describes how environmental taxes arise regulatory costs that affect national business competitiveness. While formulating tax policy, the government would determine tax base and tax rate as a base to impose amount of tax obligation which in the same time it should not prevent the business competitivenes due to cost bear by government, by business as taxpayer and by state/society. Practically, tax formula (tax rate $\mathrm{x}$ tax base) on environmental taxes will never be simple. For example, Art. 54(1) Local Tax and User Change Act stipulated that the tax base for road electricity tax is the amount of money for the sale of electricity, then Art. (2) regulated that the amount of money for the supply of electricity as mentioned in Art. (1) [19]:

a. If the electricy supplied by entities differ from the entities to whom the payment will be made, the value of electricity service supplied is that the amount of bill plus the amount of money converted to the use of each $\mathrm{kWh} /$ variable as the total of the payment. 
b. If the use of electricity is self-supply, the value of electricity is calculated based on total capacity, the rate of use, time frame of use, the price of unit used applicable for each region.

The general formula to calculate the tax should be levied based on composition of total cost is related to the composition of total cost and composition of environmetal cost [20]:

Total Cost $(I D R / k W h)=$ fProduction costs $(I D R / k W h)+$ Enviromental costs $(I D R / k W h) *$

Enviromental costs $(I D R / \mathrm{kWh})=$ fPollutant emission factors $(\mathrm{t} / \mathrm{kWh})+$ Cost Equivalent

$$
(I D R / t)^{*}
$$

Enviromental costs $=$ fresources consumption costs + pollution control cost

Based on these situation, the local government should draft the implementing regulation which is dynamically adjust to the change of tax base determinant factors such as composition of total cost and composition of environmental cost. This complicated formula describes the policy cost. In addition, the government also get burden to ensure that tax regulation has been implemented as its goal. Thus, the burden should not not solely the administrative cost, but also other cost such as collection cost, Distress Warrant or dispute settlement.This model also apply for other use of resources such as the use of gas supply [21].

Performance bonds is subjected to legal person who has forestry management permit as mentioned in Law No.35 year 1999 regarding Forestry [22]. The performance bonds is treated like a warranty of acceptable forestry management business. The bonds will be liquid once the business work meet the standardized quality of work. The performance bonds schemes seems effective enough to diminish the practice of unacceptable foresty related business and to slow down forests degradation. Then, AMDAL and UKL-UKP is a obligation of assessing whether the business comply to run their activity in the minimum level of the environmental externalities. If the business fail to comply with the minimum level externality standard, they have to pay the fines/penalty.

Based on the field study, eventhough Indonesia has applied several quasi-environmental tax, however how the money collected shall be realocated to fulfill the earmarked function, has not been clear. In addition, Indonesia has not has comprehensive legal framework to enforce if the fulfilment of quasi-environmental obligation could not meet its purpose. Similarly, as the OECD noted that the achievement of the goals are challenging enough even in the situation a particular government has comprehensive framework of collecting and allocating system of environmental tax. The OECD also noticed that it take a lot of effort to stricly enforce the regulation for the shake of fruitful result.

In imposing taxes, quasi-environmental tax, types of fines/penalities, it is very important to ensure that the amount of money paid has to be larger than the environmental degradation. It means the marginal environmental damage has to be smaller than marginal cost paid by the business to fund the preservation toward sustainable development. On the other part, if the government can convince the reliable and valid calculation formula of the amount paid commensurate with the damage, then the allocation framework comprehensive set with periodical outcomes of the money used, probably it will encourage the business or people to comply with the rule.

Considering numbers of quasi-environmental tax that probably is quaty variable on each local government/provincial government, the government need to construct a comprehensive environmental tax. The comprehensive environmental tax means that the tax tax policy, tax law and tax administration framework are in one package with clear framework of spending/earmarking system. The proposed comprehensive environmental tax will be less reluctant to comply by the business if its imposition do not add to high burden and less regulatory cost. 


\section{Conclusion}

The government of Indonesia has been aware of the need to preserve the sustainable environment and prevent the environmental damage by offer the initiation of environmental tax. However, the initiation get against by business entities for the potential additional tax burden it make that in the same time the government has not has the clear framework of environmental tax and its earmark concept. On the other hand, the government also has imposed the quasi-environmental tax through local/provincial government, similarly with less budget allocation concept. Therefore, it need to redesign the environmental tax system to minimize its convergences into other increasing number of quasies with clear earmark concept. The environmental tax system will be less reluctant if it not add high burden will less regulatory cost.

\section{Ackonwledgments}

This article is a part of Environmental Tax Series research conducted by Cluster Research Political Tax, Welfare and National Resiliency, Faculty of Administrative Science University of Indonesia lead by. Haula Rosdiana. This article is the further discussion of the article entitled "Fiscal Legitimacy of Environmental Taxation: Challenges for Green Growth Policy". These series of research are funded by Professorship Research Fund provided by Faculty of Administrative Science University of Indonesia

\section{References}

1. Handbook of National Plan Development 2012-2013. Memperkuat Perekonomian Domestik. National Planning and Development Agency

2. D. Hasan, D.E. Puspitasari. Tinjauan terhadap rencana penerapan pajak lingkungan sebagai instrumen perlindungan lingkungan hidup di Indonesia. Mimbar Hukum 20, 3 (2008)

3. K. Hardjasoemantri. Hukum Tata Lingkungan. (Gadjah Mada University Press, Yogyakarta, 2005)

4. C. Septiviani. Penetapan Nilai Pajak Lingkungan untuk Industri Tekstil. Laporan Hasil Penelitian. Institut Pertanian Bogor. (2009)

5. Indonesia Insititute of Science. Pajak untuk Peningkatan Perbaikan Lingkungan, downloaded from http://lipi.go.id/berita/pajak-untuk-peningkatan-perbaikanlingkungan/4664, (2005)

6. Zolt. Tax incentives and tax base protection issue, papers on selected topics in protecting the tax base of developing countries. United Nations Department of Economics and Social Affairs. (2013)

7. G.N. Mankiew. Principle of microeconomics (Singapore: Harvard University Press, 2004)

8. L. Seidman, K. Lewis. Compensation contribution under international carbon treaty. Working Paper Seris No.03 University of Delaware. (2009)

9. J.S. Hinman. The green economics recovery: wind energy tax policy after financial crisis and the American recovery and reinvestment tax act of 2009. Journal of Environmental Law \& Litigation 24, 1 (2009)

10. KPMG. The KPMG Green Tax Index 2013, An Exploration of Green Tax Incentives and Penalities. (2003) 
11. UN-ESCAP. Low carbon green growth roadmap for asia and the pacific, environmentl tax reform: major findings and policy implication from a multi-regional economic simulation analysis. (2012)

12. OECD. Environmental taxation a guide for policy makers. (2011)

13. E. Anom. Pemahaman ketahanan nasional dalam upaya memperkokoh keutuhan NKRI. Forum Ilmiah Indonusa 5, 3 (2008)

14. E.M. Pratiwi, G. Setyawan. Tinjauan dalam rencana pemberlakuan green tax atau eco tax di Indonesia untuk menghadapi ASEAN Economic Community 2015. Jurnal Riset Akuntansi dan Keuangan 2, 3 (2014)

15. Indonesia Chamber of Commerce. Kalangan dunia usaha menolak pajak lingkungan. (2015)

16. Suwardi D. and Ayu A.C. Formulasi kebijakaan pajak lingkungan (environmental taxation) sebagai instrumen perlindungan lingkungan hidup menurut prinsip regulerend. Depok: Universitas Indonesia. (2013)

17. Jakarta Open Data. Data rencana dan realisaasi penerimaan pajak 2015

18. Corporate act No.40 year 2007

19. Local Tax and user charge act No. 28 Tahun 2009, Republik Indonesia.

20. W. Han, D. Liu, Y. Fan, Y. Hu, Y. Xu, X. Liu. Methods research to calculate equivalent of environmental cost in power industry. Journal of Power and Energy Engineering 2, 4 (2014)

21. Nuryadin, Tb R.R. Nitibaskara, H. Herdiansyah, R. Sari. The Model of Simulation In Regional Energy Security Framework: Policy Studies PT. Cirebon Area. IOP Conference Series: Earth and Environmental Science 88 012029, (2017)

22. Law No.35 year 1999 regarding Forestry 